\title{
Disability Working Allowance
}

\section{A new allowance for people with a mental illness or disability}

\section{Philip Steadman, Registrar in Psychiatry, Queen Mary's Hospital for Children, Carshalton Beeches, Surrey SM5 4NR}

Disability Working Allowance (DWA) is for working people who have an illness or disability that puts them at a disadvantage in getting a job.

The following are some of the qualifying factors which psychiatrists need to know about (the wording is that used by the Department of Social Security).

(a) If the person is getting regular treatment for clinical depression, anxiety, phobias, panic attacks, nervous or emotional problems.

(b) If the person often gets disorientated, often forgets to turn household appliances off, always needs someone to help them with money, sometimes gets upset to the point where they attack people or break things, finds it so difficult or stressful getting on with people that it severely affects their life at home, work or leisure.

(c) If the person has had a fit or coma within the last 12 months in which they have lost consciousness.

(d) If the person is unable to work a normal working week because of physical exhaustion.

(e) If the person has difficulty understanding things or cannot make himself understood.

(f) If the person is still getting over the effects of an illness or needs time to build up his strength.

There is also a whole range of physical qualifying factors which includes problems with vision, hearing, speaking, manipulation, dexterity, pain, exhaustion, and recovery from an accident. One or more of these is sufficient and the person does not have to be mentally unwell or disabled. A physical illness or disability by itself can suffice.

To be eligible for DWA, all three of the following points must apply.

1. The person must have an illness or disability that puts them at a disadvantage in getting a job, as already covered.

2. The person must be starting to work, or already at work, for 16 hours or more a week. The work can be as an employee or self employed. It must be work that is expected to last for at least five weeks and it must be paid.
3. The person must be already getting one of a range of benefits which include Mobility Allowance.

\section{Attendance Allowance or Disability Living Allowance}

\section{How much is it?}

The full amount of DWA per week is: single person $\quad £ 42.40$ couple or lone parent $£ 58.80$ plus

child under $11 \quad £ 10.40$

child 11-15 $£ 17.25$

child 16-17 £21.45

child $18 \quad £ 29.90$

The amount actually paid depends on overall income. Overall income includes:

take-home pay

business profits

money from maintenance or tenants

social security benefits.

It does not include:

child benefit

one parent benefit

disability living allowance

housing benefit

community charge benefit.

For a single person, 70 pence is taken off the full amount for every $£ 1.00$ received each week over $£ 39.95$.

For couples and lone parents, 70 pence is taken off the full amount for every $£ 1.00$ received each week over £66.00. Any savings between $£ 3,000$ and $£ 16,000$ will affect the amount of DWA paid.

\section{How Disability Working Allowance affects other benefits}

Disability Living Allowance. This is payable as well as DWA. As already stated, DLA is not counted 
as income when working out how much DWA is due.

Housing benefit. DWA may reduce the amount of housing benefit payable.

Community charge benefit. DWA may reduce the amount of community charge benefit payable.

Family Credit. Family Credit is a Social Security benefit for people who are working for 16 hours or more a week and who have at least one child. It is not possible to get DWA at the same time as Family Credit.

For more information, your patient can be put in touch with the following sources.
Local Social Security Office (the phone number and address are in the phone book under Social Security and Benefits Agency).

The Benefit Enquiry Line for people with disabilities. The number is 0800882200 and the call is free.

A local Citizen's Advice Bureau.

\section{Note}

'Disability Living Allowance' by Dr Steadman was published in the Psychiatric Bulletin, June 1992, 16, 349-350.

\title{
Fraud and misconduct in medical research
}

\section{Summary of the report of the Royal College of Physicians}

\author{
Brian Ferguson, Secretary, Research Committee, Royal College of Psychiatrists
}

In February 1991 the Royal College of Physicians produced a report entitled 'Fraud and Misconduct in Medical Research'. Most of the cases documented have come from the United States but by the end of 1988 five cases had been formally reported in Britain. One of these was a financial fraud perpetrated by a psychiatrist who worked in a district general hospital in the Northern Region and who forged data for a drug company. He was subsequently reported to the General Medical Council by the Association of the British Pharmaceutical Industry and had his name removed from the medical register. Informal investigations, however, suggest that fraudulent research might be more widespread and as a result the Royal College of Physicians established a working party to look at this issue in detail. They recommended that a twin track approach of prevention and thorough management of complaints of misconduct be adopted. The report was kindly forwarded to the Research Committee of the Royal College of Psychiatrists which felt that a summary of these recommendations should be widely published among researchers in psychiatry.

\section{Prevention}

The first concern must be to create an awareness of the potential for piracy, plagiarism or fraud in institutions where any form of research is conducted. Students should be introduced to a code of practice at the beginning of their career with due emphasis on research ethics. Standards of integrity are best set by departmental heads and should be given a high profile within the research facility. This will entail adequate supervision of junior researchers, including monitoring of raw data. Clearly all authors whose names have been attached to a publication must have made an intellectual contribution. Ethics committees should insist on high standards for storing and inspection of data by the research team for a minimum ten year period before granting permission for the work to be undertaken. Medical notes of the subjects involved must also be audited regularly. The practice whereby applicants for psychiatric and research posts are evaluated on the number of publications they list may inadvertently encourage misrepresentation and it would therefore be preferable for an appointments committee to consider a smaller number (e.g. five to ten) of papers selected by the candidate.

Throughout the report there is emphasis on a more pro-active role by ethics committees and heads of department to ensure that high standards are maintained in all areas of medical research.

\section{Investigation and management of Complaints}

There is clearly a need to protect those who make allegations of fraud unless their complaint turns out to be mischievous or ill-founded. Conversely, researchers are entitled to an equal level of respect 